Jurnal Ekonomi Pembangunan, 18 (1), 2017, 93-101

\title{
Evaluation of Public Infrastructure: a Case of Sapon Dam Kulon Progo, Indonesia
}

\section{Nuni Budi Prastiwi ${ }^{1}$, Akhmad Makhfatih $^{2}$, Inayati Nuraini Dwiputri ${ }^{3}$}

${ }^{1}$ Directorate General of State Asset, Ministry of Finance, Indonesia

${ }^{2,3}$ Faculty of Economy and Business, Gajah Mada University

Corresponding Author: monuqniq@gmail.com

Received: January 2017; Accepted: May 2017

\begin{abstract}
One of problems in making a government's balance sheet is to determine the value of infrastructure run by the government. It is because the infrastructure is valueless and closely similar in characteristics to public goods. In general, most researchers would use travel cost method to value government infrastructure. Yet, this method is very sensitive toward respondents' characteristics and in many cases, it results in over estimated valuation. Meanwhile, a valuation technique using cost approach for government infrastructure reflects less its benefits and in many cases, it also tends to be undervalued. Against the aforementioned issue, this research attempted to evaluate state-owned infrastructure using a capitalization method. The object of this research was Sapon Dam located in Kulon Progo Regency, Indonesia. This dam is a state-owned asset functioned to sustain agricultural development particularly for irrigating paddies. This research was aimed at estimating the value of Sapon Dam using a capitalization method. In this method, the absence of infrastructure value was replaced with difference-in-differences analysis for proxy income.

The data used in this research was secondary data which included paddy planting areas in irrigated and rain-fed fields, and also farmers' net income. It was found that the estimated value of Sapon Dam per December $15^{\text {th }} 2015$ was IDR 96,659,385,018.72.
\end{abstract}

Keywords: Infrastructure valuation, capitalization approach, difference-in-differences, dam, direct capitalization.

JEL Classification: H41, Q51, Q58

\section{Introduction}

\subsection{Background}

Development programs and government policies are designed to reform the existing condition (Gertler et al., 2011). Similarly, the development program of government public assets in agriculture is expected to generate reformation such as increasing planting areas, increasing planting intensity, improving agricultural production, reducing cost of production and many others. This development is one of government's efforts to achieve food sovereignty. This research, therefore, attempts to evaluate the achievement of government programs in agriculture. The evaluation is conducted to see the impact of implemented programs.

One of methodology used in impact evaluation is difference in differences. This method identifies the program impact by comparing participants (with treatment) and non participants (without treatment), and also before and after intervention (Khandker et al., 2010). This method calculates the comparison between the average result of the areas affected by the program (participants) and the areas not affected by the program (non participants) before and after the program implementation.

Suparmoko (2009) states that identification of impact will physically provide higher analysis 


\section{Jurnal Ekonomi Pembangunan, 18 (1), 2017, 93-101}

benefits when it can be calculated in rupiah (IDR). Economic valuation can be done after conducting impact evaluation of an activity. This economic valuation is important to be conducted since it is related to macro-economic policy and decision for the allocation of production factors regarding the efficiency at the micro level.

Direct capitalization method is one of valuation methods. This method changes an estimation of single annual income into indication of value through dividing income estimation by appropriate capitalization rate (Prawoto, 2003). This research used difference in differences method to calculate net impact of the dam's construction.

Public asset valuation methods commonly used in previous studies were Depreciated Replacement Cost/DRC (Andrew and Pitt, 2000; Isnuroso, 2010; Plimmer and Sayce, 2006), Contingent Valuation Method/CVM (Chen et al., 2008; Mulangu and Kraybill, 2015) or Travel Cost Method. CVM and TCM are not appropriate enough to be used for valuation of public assets which do not have tourism benefits such as Sapon dam because they will create bias as the visitor variable would arise endogeneity. DRC method includes calculation of loss cost from physical development without looking at the benefits from public assets. In fact, dam has benefits, such as its use for irrigation.

Sapon Dam Kulon Progo is one of public assets for sustaining development in agriculture, particularly for irrigation. By capitalizing the income from agriculture generated from net impact of changes in irrigated paddy planting areas due to Sapon Dam, the economic value of Sapon Dam can be revealed. Using difference-indifferences method, public assets can be valued based on the benefits of using the dam which directly indicates its economic benefits.

\section{Literature Review}

\subsection{Economic Value of Dam}

In general, resource is defined as something considered having economic value (Fauzi, 2010).
Fauzi (2010) also states that resource is ecosystem component which provides beneficial goods and services for human needs. The facility and infrastructure of irrigation like dam is considered as jointly managed water resource because it provides benefits for human needs particularly agriculture. Therefore, dam as a resource can be said to have economic value.

Suparmoko (2009) argues that in conducting environmental economic valuation, the value on the basis of use (instrumental use or use value) is given to indicate the environment capability of the environment when it is used to meet human needs. Indonesian Valuation Standard (Komite Penilaian Standar Penilaian Indonesia/ KPSPI, 2013) mentions that value in use is the value owned by a particular property for certain use and for certain user, and therefore, it is not related to market value. This value is given by a particular property without considering the highest and best use from those properties or the amount of money obtained from its sales.

Value in use includes non market value (KPSPI 2013). Meanwhile, public sector assets as an asset owned or occupied by government or quasi government entities are targeted to provide goods and services for public. Valuation of public sector assets can be carried out for economic analysis by the government to determine whether the assets are efficiently used and managed (KPSPI 2007)

\subsection{Net Income}

Net income is the difference between the Total Revenue (TR) and Total Cost (TC). Factors affecting income are output and input quantity as well as both prices. Moreover, the amount of profits is a function of price, quantity of produced output and quantity of used input (Boediono, 2002).

Revenue is obtained from multiplying the total productions in units by a price per unit. Total cost is defined as all input values spent for production processes. The cost is classified into fixed cost and variable cost. Fixed cost is relatively constant from time to time and it is 


\section{Jurnal Ekonomi Pembangunan, 18 (1), 2017, 93-101}

not influenced by commodities and the amount of production which will be generated. Variable cost is influenced by the fluctuation in production.

\subsection{Valuation Approach}

In valuation, direct capitalization method can be used to obtain indication of value. Direct capitalization is one of valuation methods using income approach. Market-based valuation approach can be used for non market-based valuation, but it will generally involve the purpose which does not provide market value (KPSPI 2013). Income approach is based on the annual net income received from Property Company. This approach is then capitalized with a factor of certain capitalization rate to obtain the value. Direct capitalization method uses the assumption that the received income in the coming years will be similar or reflected as the income at the valuation year (Harjanto and Hidayati, 2014). The formula for direct capitalization method is as follows.

$$
\text { Value }=\frac{N O I}{R_{0}}
$$

In which, NOI is Net Operating Income and $R_{0}$ is Overall Capitalization Rate.

In obtaining the indication of dam's economic value, the direct capitalization method is used by changing the estimation of annual average income in the agricultural sector which increases as the dam becomes the indication of value. The used capitalization rate needs to concern the fact that the dam is a public facility owned by the government which gives social benefits. This method also shows the calculation of Year Purchase in Perpetuity (Harjanto and Hidayati, 2014) with the assumption that the dam will endlessly operate.

Generally, public assets are valued by using cost approach. In Indonesian Valuation Standard (KPSPI, 2007), there are several methods used in valuation of public sector assets for financial statement, such as Depreciated Replacement Cost, Restoration Cost Approach, and Service Unit Approach. Other considerations can be given for public asset valuation such as historical assets and non-agricultural biological assets. In such assets, another valuation method can be used through quantitative measurement such as the number of a museum's visitors or qualitative measurement such as social benefits from maintaining uneconomic facilities in a certain location.

\subsection{Social Discount Rate}

Gray et al., (1993) estimate social discount rate by using marginal productivity of capital in private sectors which is represented by real interest rates applied in capital markets. Marginal productivity of capital in the private sector is the logrolling which can be obtained from one additional unit of investment in the sector. Based on the assumption that every government investment unit replaces the number of certain private investments, this number is considered relevant for estimation of social discount rate. Therefore, the use of alternative funding sources invested in the government projects is a private investment which creates marginal products.

If the interest rate according to the prevailing price is called $i$, and inflation rate is called $f$, the real interest rate $(r)$ is formulated below.

$r=(i-f) /(1+f)$

The interest rate on the report of Bank Indonesia is indicated by lending interest rate from banks in Indonesia, while the inflation rate is shown in the report of inflation (Consumer Price Index) based on the calculation of annual inflation. The calculation of real interest rate with above formulation will provide an estimation number about the marginal product of private capital in Indonesia which will be used as estimation of social discount rate. 


\section{Jurnal Ekonomi Pembangunan, 18 (1), 2017, 93-101}

\subsection{Previous Studies}

The previous studies related to dam and irrigation areas commonly used Depreciated Replacement Cost method/DRC (Andrew and Pitt, 2000; Isnuroso, 2010; Plimmer and Sayce, 2006), Contingent Valuation Method/CVM (Mulangu and Kraybill, 2015;) or Travel Cost Method/TCM. Mulangu and Kraybill (2015) conducted costbenefit analysis on the improved irrigation area when faced with the risk of climate change on Mount Kilimanjaro, Tanzania, Africa. Contingent valuation method (CVM) was used to determine the farmers' willingness-to-pay (WTP). The results of study indicate that farmers are willing to pay $7 \%$ up to $21 \%$ of the annual agricultural wage to obtain irrigation.

Michailidis et al., (2007) used a combination of real options and Discounted Cash Flow (DCF) approach to conduct economic social valuation in the construction plan of irrigation system project of Petrenia Dam in North Greek. The concept of real options is extended by DCF to be more flexible in evaluating the project in the uncertain investment environment. The analysis result using the combination of real option and DCF indicates that the value of delay increases as the uncertainty increases which means that the construction is better to be delayed until better information is obtained.

The conducted valuation in a new irrigation area in Lerma Basin, Spain during 10 years of irrigation for efficient water use and irrigation performance. The valuation was carried out over periods of time before the irrigation transformation (2004 - 2005), during the transformation (2006 - 2008), and after the transformation (2009 2013). The result of this study showed that the irrigation became the main water input of $60 \%$ while evapotranspiration contributed the main water output of $70 \%$. The irrigation efficiency achieved as much as $76.1 \%$ while the loss due to evaporation and wind stream was $13.5 \%$ and a small portion of drainage was $10.4 \%$. Water deficit was estimated as much as $17.8 \%$. The efficiency of irrigation increased by $1.05 \%$ per year, while the fraction of irrigation water drainage decreased by $0.95 \%$ per year.

Muchara et al. (2014) valued the irrigation water for potato farmers within irrigation scheme in Mooi River, KwaZulu-Natal Province, South Africa. The applied method was residual value method to estimate water value among small farmers who focused on the potato planting. The results of this research illustrated that the water which was provided freely to most of the consumers, generally caused imbalance water distribution, bad water management, and inefficiency in water use.

Widodo (2008) conducted a study to calculate water resources economic value on Sungapan Dam in Pemalang Regency, Central Java. The data was obtained over a period of time after the dam's construction in 1999-2006 in the irrigation area of Sungapan Dam and also dry area outside the irrigation area. The data was analyzed using Benefit Cost Analysis with Residual Imputation Analysis method. The result of this study was that during the period of 1999 - 2006, Sungapan Dam had given benefits and profits as much as Rp599,830.25 per hectare per year to the landlords. The amount of cumulative property value using income approach was $\mathrm{Rp} 102,571,615,504.00$.

Isnuroso (2010) conducted a study to value public assets of Nambo Dam and its irrigation located in Pemalang Regency, Central Java. As this dam's building and irrigation is classified into property with a special character, Depreciated Replacement Cost (DRC) was employed for the valuation and the straight-line method was used for the physical depreciation of building. Isnuroso (2010) concluded that the asset fair value of Nambo Dam and its irrigation per $31^{\text {st }}$ December 2009 was $\operatorname{Rp} 22,197,574,387.28$.

\section{The Research Method 3.1 Impact Evaluation}

Gertler et al. (2011) define impact evaluation as an evaluation which attempts to make a casual connection between a program or intervention and the expected result. Impact evaluation studies 


\section{Jurnal Ekonomi Pembangunan, 18 (1), 2017, 93-101}

whether the change is due to pro-intervention and not because of other programs (Khandker et al., 2010).

Impact evaluation is conducted to know whether the treatment made in an area is effective compared to the area without any intervention program. In practice, another group or region is required as a comparator which is not exposed to the treatment. This is called counterfactual as an estimation of what the result will be for program recipients if they are absent in the program. By definition, counterfactual cannot be observed, and therefore is estimated by using a comparison group (Gertler et al., 2011).

Khandker et al. (2010) explain that differencein-differences basically compares the groups which get treatment with the groups which do not get treatment in terms of observing outcome changes from the time before and after the treatment. This program provides 2 period settings including before the program $(t=0)$ and after the implementation of the program $(t=l)$. The outcome for each treatment beneficiary and its comparator as counterfactual is denoted with $Y t^{T}$ and $Y t$ in time $t$. Differencein-differences method estimates the average treatment impact as follow:

$$
D D=E\left(Y_{1}^{T}-Y_{0}^{T} \mid T_{1}=1\right)-E\left(Y_{1}^{C}-Y_{0}^{C} \mid T_{1}=0\right)
$$

$T_{1}=1$ indicates the treatment or area which encounters project at $t=l$, while

$T_{1}=0$ indicates the area which does not encounter the treatment or project.

\subsection{Method of Collecting Data}

The design of this study is explanatory research. Explanatory research focuses on testing theory which had established on the context of different research. For data collection, explanatory research uses non communication method through observation, experiment, and literature review. The type of data used in this research was secondary data obtained from Bank Indonesia, Central Bureau of Statistic, Central Region of Serayu-Opak River, Public Work
Office, and Management of Energy and Mineral Resources Yogyakarta Province, Public Work Office of Kulon Progro Regency, and Center for Agriculture, Livestock and Marine in Lendah District, Galur, Panjatan.

\subsection{The Method of Data Analysis}

At the beginning, this research identified the result chain of construction of Sapon dam related to its irrigation. This identification was then used as the basis for conducting impact evaluation by using difference-in-differences method. The result of this method was in the form of estimated net impact on the change of the paddy plant area in Sapon dam. Further analysis was conducted to calculate the farmers' input and output per hectare using Farm Business Analysis. The result of this Farm Business Analysis was in the form of net income of paddy farmers per hectare.

The last method used was direct capitalization method. This method was used to obtain indication of value of Sapon dam by capitulating per year income received from the agriculture sector due to the existence of Sapon dam. The capitalization rate used social discount rate which was estimated by using marginal productivity of capital. The formulation for estimating the indication of value of Sapon dam is given below:

Indication of Economic Value $=$

Net Impact X NOI Farm Business per Ha Social Discount Rate

\section{The Results}

\subsection{Impact Evaluation using Difference- in-Differences Method}

The sequences of the result chain were started from input of water in Progo River, human resources involved, budget and irrigation networks. The activity was mapped with irrigation work to change the input into output in the form of irrigation water. From this implementation, results such as outcomes and final outcomes were obtained. After the output was utilized, the rice field got enough water irrigation to plant the 
paddy. The extension area of irrigated paddy plant became the final result or net impact of Sapon dam development in 2010. Thus, the time limit of the identified period was before and after 2010 in order to see the water discharge of the dam. This could be then assumed that the dam was fully operated since 2010 . The calculation of net impact of the dam toward the area of rice field irrigation was based on the assumption that irrigation was only used during the planting season.

The average area of rice field for planting paddy which could be irrigated around Sapon area during the period before Sapon was established was 3,497.5 ha per year. Meanwhile, the average area of rice field for planting paddy which could be irrigated around Sapon area during the period after Sapon was established was 3,620 ha per year. The difference of 122.5 ha indicated the estimation of an increase of rice field area which can be irrigated for planting paddy due to the establishment of Sapon dam.

The rain-fed area was used as a comparison group. This area was selected because it was located in the same district, and therefore, its situation was relatively similar to those in the irrigated field. Yet, this rain-fed area did not get water irrigation from Sapon dam or other irrigation networks. This comparison group was used as contra-factual to show the estimation of change occurred when Sapon dam was not established at the same time in the treatment area. An assumption was made for this rain-fed area that the field was only planted paddy once a year. The estimation of impact of Sapon dam by using differences-in-differences method is presented in the Table 1.

It can be seen from Table 1 . that the average area of the rain-fed for planting paddy in the period before Sapon dam is established was 205.8 ha per year, while after the dam is established, it is 180 ha per year (BPS, 2015). The difference of -25.8 ha indicates the estimation of a decrease of the rainfed area for planting paddy after 2010. The above differences of the irrigated field area and the rain- fed field area for planting paddy before and after the dam's establishment generate a final result or net impact as much as $148.34 \mathrm{Ha}$. This number indicates the result of impact evaluation of Sapon dam establishment for irrigating rice field using difference-in-differences method. It was also found that there was a change in the planted area as an additional planted area as much as 148.34 ha net due to the dam existence.

Table 1. The Estimation of Impact Sapon Dam to the Area of Rice field

\begin{tabular}{cccc}
\hline & Before & After & Difference \\
\hline $\begin{array}{c}\text { Treatment } \\
\text { Group }\end{array}$ & $3.497,50$ & $3.620,00$ & 122,50 \\
$\begin{array}{c}\text { Comparison } \\
\text { Group }\end{array}$ & 205,80 & 180,00 & $-25,80$ \\
Difference & $3.291,70$ & $3.440,00$ & 148,34 \\
\hline \multicolumn{2}{c}{ Source: Badan Pusat Statistik, calculated }
\end{tabular}

Note: Treatment Group: Irrigated rice-planting area by Sapon Dam; Comparison Group: Rain fed rice-planting area

\subsection{Farm Business Analysis}

Farm Business Analysis estimates the average farm net income per hectare in 2014 in the district of irrigated areas of Sapon dam. Data of input volume and input unit price were obtained from component data AUT in BP3K (Center for Agriculture, Livestock and Marine) in Lendah District, Galur, Panjatan in 2014. Total revenue per year was Rp39,545,850.00 derived from the sale of $8,700 \mathrm{~kg} / \mathrm{ha}$ dry grain harvest which cost Rp4,545.50/kg (BPS, 2015). Total cost per hectare was obtained from the total production input of $\mathrm{Rp} 19,450,000.00$ in the form of variable cost which consisted of Means of Rice Production (seed, fertilizer, pesticide, and herbicide) and labor cost and also from fixed cost of Rp2,693,250.00 which consisted of land rent, land tax and Irrigation Service Fee. This Farm Business Analysis indicated that the estimation of farm net income for every hectare of rice field in Sapon irrigation areas which were planted with paddy was $\operatorname{Rp} 17,402,600.00$. 


\section{Jurnal Ekonomi Pembangunan, 18 (1), 2017, 93-101}

\subsection{Economic Value of Dam}

In Indonesian Valuation Standard, difference-in-differences method is not recognized for valuation of public assets. However, in this research, this method was used as proxy income approach using direct capitalization method. Income was calculated based on benefits or impact resulted from these assets.

The impact evaluation on the construction of Sapon dam using difference-in-differences approach revealed a change of expansion of irrigated area for planting paddy as much as 148.3 ha. Estimation of farm business net income per hectare in 2014 in the district of Sapon irrigated area was $\mathrm{Rp} 17,402,600.00$. Therefore, the increasing total net income from agriculture sector in 2014 due to the existence of Sapon dam was $\operatorname{Rp} 2,580,805.00$.

With the assumption that the income received in the coming years will be exactly the same as the income in 2014, and that the dam would be utilized forever, the economic value of the dam could be obtained by capitalizing the total net income per year using social discount rate. While the average of lending interest rate of banks in Indonesia in 2014 was $13.41 \%$ and the average of inflation rate in 2012 was $6.24 \%$, the social discount rate could be generated as much as 2.67 percent (equation 2). The result of direct capitalization showed an indication of economic value of Sapon dam toward agricultural sector for irrigating rice field dated December $15^{\text {th }} 2015$ as much as Rp 96,659,385,018.72 (equation 1).

\section{Conclusion and Suggestion}

This research applied difference-indifferences method as income approach to conduct economic valuation of public assets. It was conducted in Sapon dam which provided an impact on the expansion of irrigated rice field area utilized for planting paddy. The income was calculated from net income of farm business on the irrigated rice field which increased due to the existence of Sapon Dam.
This research measured the direct impact of the dam in the form of an increase of planted area in irrigated areas and rain-fed areas (with and without treatment) in the period before and after the dam's construction. Based on the results of the analysis, discussion, formulation and research question, it can be concluded that the estimation of Sapon dam's economic value toward agricultural sector for irrigating rice field by using difference-in-differences method as proxy income approach dated December $15^{\text {th }} 2015$ was about $R p$ $96,659,385,018.72$.

Based on the conclusion above, there are several research implications such as: 1) The research result indicates that the impact evaluation approach using difference-indifferences method can be used as a basis in determining economic value of public assets with income approach. Therefore, this method can be used to determine economic value of public assets and to conduct impact evaluation occurred due to the existence of Sapon dam; 2) The impact evaluation approach using differencein-differences method will enhance valuation repertoire using income approach to value public assets.

This research is limited based on the following aspects: 1) This research only calculates the impact of the dam toward agricultural sector with an assumption that irrigation is only for paddy plantation; 2) The planted paddy area in the irrigated area is based on a comprehensive data system as a plan for planting paddy which will be conducted in the upcoming planting season period; 3) The rain-fed field is used as comparator group with an assumption that the rice planting season is conducted once a year; 4) The capitalization rate for government projects uses the modest approach namely marginal productivity of capital in private sectors (rate of time preference) to estimate social discount rate.

Based on the limitations above, some suggestions are addressed for conducting further studies as follows: 1) economic value can be added 
from a dam's impact toward other sectors beside agriculture and irrigation of paddy planting, such as income from fishery sector and irrigation of crops; 2) data of planting area can refer to realization data of planting area which obtain the flow of irrigation; 3) intensity of paddy planting in a rain-fed field can be calculated more than one time based on its realization; 4) capitalization rate can refer to other social discount rates such as by using social opportunity cost of capital in Indonesia or by weighting average capital productivity and rate of pure time preference.

\section{References}

Andrew, A. dan Pitt, M. (2000). "Aset Valuation of Specialized Public Sector Listed Building by Depreciated Replacement Cost". Journal of Property Investment and Finance 8(6): 627636.

Badan Pusat Statistik. (2015). "Kulon Progo Dalam Angka 2005 - 2015”. www.bps.go.id accessed in $23^{\text {th }}$ October 2015.

Badan Pusat Statistik. (2015). "Statistik Harga Produsen Gabah Daerah Istimewa Yogyakarta 2014". www.bps.go.id accessed in $14^{\text {th }}$ December 2015.

Boediono. (2002). Seri Sinopsis Pengantar Ilmu Ekonomi No 1 Ekonomi Mikro. $2^{\text {nd }}$ edition. BPFE, Yogyakarta.

Chen, Y., C. Chen, dan T. Hsieh. (2008). "Evaluation of the Economic Value of World Cultural Heritage-Learning from the Example of the Great Wall of China". The Journal of American Academy of Business 13(2). ISSN: 1540-1200.

Fauzi, A. (2010). Ekonomi Sumber Daya Alam dan Lingkungan / The Economics of Natural Resources and Environment. Penerbit PT Gramedia Pustaka Utama, Jakarta.

Gertler, P.J., Martinez, S., Premand, P., Rawlings, L.B., Vermeersch, C.M.J. (2011). Impact Evaluation in Practice. The World Bank, Washington, D.C.
Gray, C., Simanjuntak, P., Sabur, L.K., Maspaitella, P.F.L., Varley, R.C.G. (1993). Pengantar Evaluasi Proyek, PT Gramedia Pustaka Utama, Jakarta.

Harjanto, B., Hidayati, W. (2014). Konsep Dasar Penilaian Properti, $2^{\text {nd }}$ edition. BPFE, Yogyakarta.

Isnuroso, Dedy. (2010). Penilaian Aset Publik Bendung dan Irigasi Studi Kasus Pada Bendung Nambo dan Irigasinya di Kabupaten Pemalang Provinsi Jawa Tengah, 2009. Unpublished Thesis. Program Pasca Sarjana UGM. Yogyakarta.

Khandker, S.R., Koolwal, G.B., Samad, H.A. (2010). Impact Evaluation, Quantitative Methods and Practices. The World Bank, Washington, D.C.

Komite Penilaian Standar Penilaian Indonesia (KPSPI). (2013). Kode Etik Penilai Indonesia dan Standar Penilaian Indonesia 2013 (KEPI \& SPI 2013). CV. Gelora Karya Bharata, Jakarta.

Komite Penilaian Standar Penilaian Indonesia (KPSPI). (2007). Standar Penilaian Indonesia (SPI). Jakarta.

Michailidis, A., Mattas, K., Tzouramani, I., Karamouzis, D. A (2009). "A Socioeconomic Valuation of an Irrigation System Project Based on Real Option Analiysis Approach". Journal of Water Resour Manage 23: 1989 2001.

Muchara, B., Ortmann, G., Mudhara, M., Wale, E. (2014). "Irrigation water value for potato farmers in the Mooi River Irrigation Scheme of KwaZulu-Natal, South Africa: A residual value approach". Journal of Agricultural Water Management 164: 243 - 252.

Mulangu, F., Kraybill, D. (2015). "A cost-benefit analysis of improved irrigation when faced with the risks of climate change on Mount Kilimanjaro". Journal of Water Resources and Economics 10: $31-44$. 
Avalaible online at http://journals.ums.ac.id

Jurnal Ekonomi Pembangunan, 18 (1), 2017, 93-101

Plimmer, F dan S. Sayce. (2006). "Depreciated Replacement Cost Consistent Methodology?" Proceeding of the 2010 XXIII FIG Congress in Munich, Germany.

Prawoto, A. (2003). Teori dan Prakterk Penilaian Properti. BPFE, Yogyakarta.

Suparmoko. (2009). Panduan dan Analisis Ekonomi Sumber DayaAlam dan Lingkungan
(Konsep dan Metode Penghitungan), $1^{\text {st }}$ edition. BPFE, Yogyakarta.

Widodo, Wahyu. (2008). Nilai Ekonomi Sumber Daya Air: Studi pada Bendung Sungapan di Kabupaten Pemalang Provinsi Jawa Tengah 1999 - 2006. Unpublished Thesis. Universitas Gadjah Mada. Yogyakarta. 